\title{
Monitoring and mapping of seasonal vegetation trend in Tamil Nadu using NDVI and NDWI imagery
}

\section{P.J. Prajesh*}

Department of Remote Sensing and GIS, Tamil Nadu Agricultural University, Coimbatore (Tamil Nadu), India

\section{Balaji Kannan}

Department of Soil and Water Conservation Engineering, Tamil Nadu Agricultural University, Coimbatore (Tamil Nadu), India

\section{S. Pazhanivelan}

Department of Remote Sensing and GIS, Tamil Nadu Agricultural University, Coimbatore (Tamil Nadu), India

\section{R. Kumaraperumal}

Department of Remote Sensing and GIS, Tamil Nadu Agricultural University, Coimbatore (Tamil Nadu), India

\section{K.P. Ragunath}

Department of Remote Sensing and GIS, Tamil Nadu Agricultural University, Coimbatore (Tamil Nadu), India

*Corresponding author. E-mail: iamprajesh17@gmail.com

\begin{abstract}
In order to monitor vegetation growth and development over the districts and land covers of Tamil Nadu, India during the crop growing season viz., Khairf and Rabi of 2017, Moderate Resolution Imaging Spectroradiometer (MODIS) derived surface reflectance product (MOD09A1) which is available at $500 \mathrm{~m}$ resolution and 8-day temporal period was used to derive a time series based Normalized Difference Vegetation Index (NDVI) and Normalized Difference Water Index (NDWI) for monitoring and mapping terrestrial vegetation trend analysis which showed areas in Tamil Nadu having vegetation greening and vegetation browning. The regression slope values derived from the trend analysis was utilized and the NDVI and NDWI seasonal trend showed majority of area in Tamil Nadu falling under positive trend during the Kharif season (86.52 per cent for NDVI and 90.29 per cent for NDWI). While irrespective of land cover classes, NDVI and NDWI during Kharif season showed a greater positive trend (greening) with least negative trend (browning) for vegetation growth over the land covers whereas during Rabi season it was observed to have a mix of positive trend and negative trend over the land covers. This study was carried out to show that a systematic study can be done for understanding changes over the landscape through the use of high spatial resolution satellite dataset such as MODIS, which provides detailed spatial and temporal description at regional scale. While a trend analysis using regression slope values can be considered for demonstrating the spatial and temporal consistency on land and vegetation dynamics.
\end{abstract}

Keywords: NDVI, NDWI, Negative Trend, Positive Trend, Vegetation Greening/Browning

\section{INTRODUCTION}

Vegetation is part of terrestrial ecosystem which consists of all plants that varies from evergreen forests to grassy meadows and croplands. While vegetation covers a considerable part of earth surface it plays a major role in influencing water cycle, earth energy absorption and global climate changes (Piao and Fang 2003; Fu et al., 2014). Since vegetation cover is spread over majority of land area, the use of multiple remotely sensed datasets has been largely incorporated for large scale changes and trend detection in vegetation

\section{Article Info}

DOI:10.31018/jans.v11i1.1964

Received: December 15, 2018

Revised: January 22, 2019

Accepted: February 2, 2019

\section{How to Cite}

Prajesh, P.J. et al. (2019). Monitoring and mapping of seasonal vegetation trend in Tamil Nadu using NDVI and NDWI imagery. Journal of Applied and Natural Science, 11(1): 54- 61 
and space.

Incorporating the vegetation information derived information from satellite-sensor imagery which are characterized and interpreted depending upon the canopy spectral characteristics, various vegetation indices have been developed based on visible and near-infrared (NIR) channels for terrestrial ecosystem behavioral changes. Out of which NDVI that is based on the ratio of spectral reflectance between red and near-infrared channels is the most popular and widely used vegetation index for assessing the vegetation health and density (Tucker, 1979). However, with NDVI showing tendency to get saturated over an area having leaf area index of 3 or greater, NDWI was proposed as a complimentary index which is based on the ratio of spectral reflectance between near- infrared and short-wave infrared channels (Gao 1996) that identified crop-water status within the vegetation. Introduction of new satellites and sensors during the late 1990's such as Satellite Pour I 'Observation de la Terra Vegetation (SPOT VGT), Terra/Aqua Moderate Resolution Imaging Spectroradiometer (MODIS), Envisat Medium Resolution Imaging Spectrometer (MERIS) has been providing continuous time series products at various spatial and temporal resolutions for global change study (Schucknecht et al., 2013; Mao et al., 2012; Fensholt et al., 2009). However, in a large-scale vegetation studies MODIS lower spatial resolution and temporal period has been used which proves to be practically and also economically available for near-time use. MODIS surface reflectance product that are obtained at either 250 $\mathrm{m}$ with 2 bands or at $500 \mathrm{~m}$ with 7 bands provides n-days composite images is a successor of AVHRR with its onboard sensors Aqua and Terra providing daily data of the earth surface which can be used in understanding the global dynamics occurring over land and ocean covered areas (Gumma et al., 2011: Thenkabail et al., 2004).

In this study, seasonal NDVI and NDWI imagery which are often used for revealing vegetation changes that occurs due to abrupt changes in vegetation as a result of disturbance such as flood, urbanization, drought or insect attack was utilized for detection of vegetation greening and browning trend based on linear regression analysis.

\section{MATERIALS AND METHODS}

Study area: Tamil Nadu which is situated in the South-Eastern part of Indian Peninsular region that lies between $8.5^{\circ} \mathrm{N}$ and $13.35^{\circ} \mathrm{N}$ latitude and $78.35^{\circ} \mathrm{E}$ and $80.20^{\circ} \mathrm{E}$ longitude (Fig.1) is the $11^{\text {th }}$ largest state of India in terms of area and has total area coverage of 13 Mha along with wide range of biomes (Table 1) and coastline covering $1076 \mathrm{~km}$ (Ramesh et al., 2008). The physiography can be divided into four zones viz., Eastern Ghats, West- ern Ghats, Coastal Plains and the Central Plateau. The north-western, western and southern parts are hilly and rich in vegetation, with Western Ghats effectively blocking much of rain bearing clouds of South West Monsoon from entering the state. The eastern parts are fertile coastal plains and northern parts are a mix of hills and plains. The central and the south-central regions are arid plains and receive less rainfall than other regions. MODIS data product: MODIS onboard terra sensor surface spectral reflectance product (MOD09A1) was downloaded from the NASA developed earth data website (http:// search.earthdata.nasa.gov). The terra-based sensor that provides multispectral, temporal and angular data between medium to coarse resolution, land cover characterization was captured as h25v7 and h25v8 gridded tiles for entire Tamil Nadu at 500 meter spatial resolution and at 8-day temporal resolution. The pre-processing of the two gridded tiles was done using MODIS Reprojection Tool (MRT), where the two tiles (h25v7 and h25v8) is mosaicked, reprojected from sinusoidal projection to Transverse Mercator projection and subsetted for the extent of Tamil Nadu.

Vegetation indices extraction: Plants absorb solar radiation in photosynthetically active radiation (PAR) spectral region (Gandhi et al., 2015) as a result vegetation indices are calculated based on the response of plant in red, infrared region or short wave infrared region of the electromagnetic spectrum. Using rater calculator under GIS environment, NDVI and NDWI was extracted using equation 1 and equation 2 respectively.

$$
\begin{aligned}
& \text { NDVI }=\frac{\rho(N I R-R e d)}{\rho(\text { NIR-Red })} \\
& \text { NDWI }=\frac{\rho(N I R-S W R R)}{\rho(N I R+S W R)}
\end{aligned}
$$

In this study, NDVI and NDWI images for the cropping seasons of 2017 was generated by considering the surface reflectance and while the extraction of vegetation index values using raster calculator were represented in a value scale. Theoretically, values are represented as a ratio ranging in values from -1 to 1 but in practice the higher index values were associated with greater biomass, while the index value for bare soil, non-vegetated areas and water bodies falls close to near 0 .

Pixel based trend analysis: A linear regression model was fit to the time series images of NDVI and NDWI separately both for Kharif and Rabi seasons. The temporal trends with time series data sets were determined using linear regression model, with time as independent variable and NDVI / NDWI as dependent variable. The Linear Regression model was fit between every pixel of time series data. An output image was generated which indicates the slope of the regression line. Positive slope (values more than 0 ) indicates in- 
creasing trend and negative slope (values less than 0 ) indicates decreasing trend. A pixel value nearer to zero indicates no specific trend in those pixels. A linear regression model adapts the following equation:

$\mathrm{Y}=\mathrm{mX}+\mathrm{c}$

Where $Y$ is the dependent variable, viz., time series data of NDVI, NDWI

$\mathrm{m}$ is the slope of the regression line

$X$ is the time variable

$\mathrm{C}$ is the $\mathrm{y}$-intercept

NDVI and NDWI based spectral variations can very well be utilized to explore the relationship difference between temporal spectral profiles and seasonal dynamic in order to assess the general environmental trends and phenological parameters (Cuomo et al., 2001). The trend analysis was carried out on the 8-day interval NDVI and NDWI images.

To interpret the trend, result over the seasonal NDVI and NDWI raster a series of zonal histogram was carried out with respect to land cover and district boundaries as zones. An overall methodology followed in this study for monitoring and mapping of vegetation growth based on the vegetation indices has been depicted in Fig. 2 .

\section{RESULTS}

Regression slope values derived from a trend analysis could demonstrate spatial and temporal consistency on land and vegetation dynamics (Guo et al., 2017); a pixel based linear regression

Table 1. Different Land Cover of Tamil Nadu and their geographical area.

\begin{tabular}{lll}
\hline S.N. & Land Cover & Area $\mathbf{( s q .} \mathbf{k m}$. ) \\
\hline 1. & Built-up & 5291.638 \\
2. & Cropland (Kharif) & 5232.520 \\
3. & Cropland (Rabi) & 13630.054 \\
4. & Forest-Deciduous & 8684.932 \\
5. & Forest- Evergreen & 5434.104 \\
6. & Forest-Swamp & 166.525 \\
7. & Forest-Scrub & 2559.801 \\
8. & Plantation Land & 9067.513 \\
9. & Wasteland & 5361.469 \\
10. & Water bodies & 8301.206 \\
11. & Wetland & 947.958 \\
\hline
\end{tabular}

Table 2. Percentage of pixels under vegetation greening (positive trend) and vegetation browning (negative trend) during Kharif season and Rabi season of 2017 in Tamil Nadu.

\begin{tabular}{llll}
\hline \multicolumn{4}{c}{ NDVI trend } \\
\hline Season & $\begin{array}{l}\text { Positive trend } \\
\text { (Per cent) }\end{array}$ & $\begin{array}{l}\text { Negative trend } \\
\text { (Per cent) }\end{array}$ \\
\hline Kharif & 86.52 & 13.48 \\
Rabi & $\begin{array}{l}59.72 \\
\text { NDWI Trend }\end{array}$ & 40.28 \\
& $\begin{array}{lll} \\
\text { Season }\end{array}$ & $\begin{array}{l}\text { Positive trend } \\
\text { (Per cent) }\end{array}$ & $\begin{array}{l}\text { Negative trend } \\
\text { (Per cent) }\end{array}$ \\
\hline Kharif & 90.29 & 9.71 \\
Rabi & 40.26 & 59.75 \\
\hline
\end{tabular}

analysis was performed on MOD09A1 surface reflectance data for Tamil Nadu. The following sub sections explain the results of pixel based linear trend analysis of vegetation indices viz., NDVI and NDWI for Kharif and Rabi seasons of 2017 in Tamil Nadu.

NDVI and NDWI Trend during Kharif and Rabi season: The spatial distribution for the pixel-based seasonal NDVI trend during the Kharif season (Fig. 3) and Rabi season (Fig. 4) shows greater percentage of pixels areas under positive trends (86.52 per cent) during Kharif season when compared to Rabi season (59.72 per cent) (Table 2).The spatial distribution for the pixel-based seasonal NDWI trend during the Kharif season (Fig. 5) and Rabi season (Fig. 6) shows greater percentage of area falls under positive trends (90.29 per cent) during Kharif season while during the Rabi season greater percentage of area falls under negative trend (59.75 per cent) in Tamil Nadu (Table 2).

NDVI Trend during Kharif season: During Kharif season (Fig. 7), it is observed that majority of

Table 3. Land Cover wise area in Tamil Nadu showing vegetation trend based on NDVI during Kharif season and Rabi season of 2017.

\begin{tabular}{lll}
\hline Land Cover & $\begin{array}{l}\text { Kharif season } \\
\text { Positive trend } \\
\text { (Per cent) }\end{array}$ & $\begin{array}{l}\text { Negative trend } \\
\text { (Per cent) }\end{array}$ \\
\hline Cropland & 90.74 & 9.26 \\
Plantation Land & 79.16 & 20.84 \\
Forest & 70.05 & 29.05 \\
Scrubland & 79.06 & 20.55 \\
Swamp Forest & 97.47 & 2.53 \\
\hline \multicolumn{3}{l}{ Rabi Season } \\
\hline Land Use & Positive trend & Negative trend \\
& (Per cent) & (Per cent) \\
\hline Cropland & 67.35 & 32.65 \\
Plantation Land & 64.56 & 35.44 \\
Forest & 63.23 & 36.77 \\
Scrubland & 56.84 & 43.16 \\
\hline
\end{tabular}

Table 4. Land Cover wise area in Tamil Nadu showing vegetation trend based NDWI during Kharif season and Rabi season of 2017.

\begin{tabular}{lll}
\hline Land Use & $\begin{array}{l}\text { Kharif Season } \\
\text { Positive trend } \\
\text { (Per cent) }\end{array}$ & $\begin{array}{l}\text { Negative trend } \\
\text { (Per cent) }\end{array}$ \\
\hline Cropland & 94.43 & 5.57 \\
Plantation Land & 80.49 & 19.51 \\
Forest & 87.39 & 12.61 \\
Scrubland & 92.60 & 7.60 \\
Swamp Forest & 99.77 & 0.23 \\
\hline \multicolumn{3}{l}{ Rabi Season } \\
\hline Land Use & Positive trend & Negative trend \\
& (Per cent) & (Per cent) \\
\hline Cropland & 52.44 & 47.56 \\
Plantation Land & 46.86 & 53.14 \\
Forest & 27.18 & 78.82 \\
Scrubland & 25.07 & 74.93 \\
Swamp Forest & 25.80 & 74.19 \\
\hline
\end{tabular}




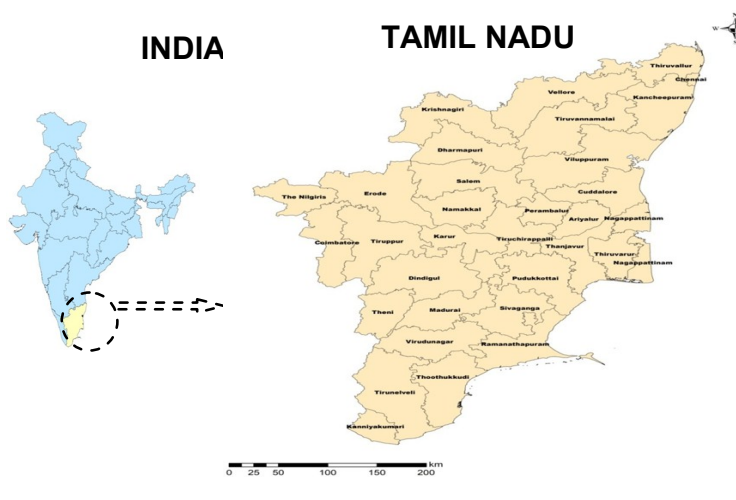

Fig. 1. Study area map with district boundaries of Tamil Nadu. Source: Department of Remote Sensing and GIS, TNAU, Coimbatore

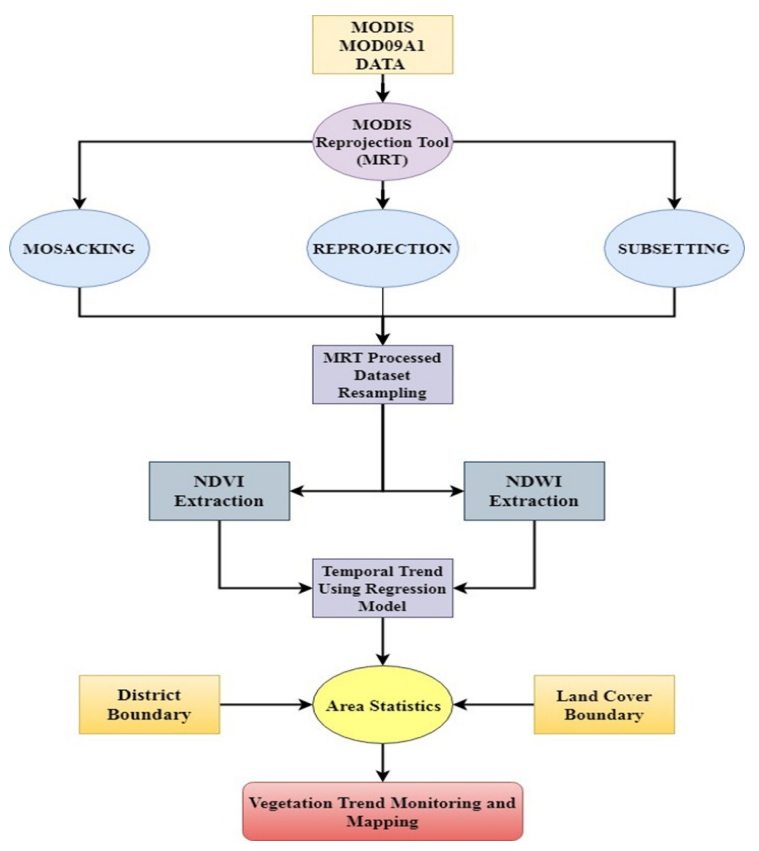

Fig. 2. Methodology for vegetation trend monitoring and mapping in Tamil Nadu during cropping season of 2017.

districts in Tamil Nadu experiences positive NDVI trend. Some of the districts with very higher percentage of areas under positive NDVI trend include Perambalur (98.95 per cent), Thiruvallur (98.76 per cent), Madurai (98.55 per cent), Kancheepuram (98.32 per cent), Ariyalur (97.61 per cent) Vellore (94.56 per cent) and Tiruvannamalai (93.34 per cent). However, it was noticed that The Nilgiris was only district in Tamil Nadu that showed greater percentage of area (59.98 per cent) under negative NDVI trend unlike other states which had greater percentage of land areas under positive NDVI trend. A few districts showed significant amount of area under negative NDVI trend such as Kanniyakumari (36.04 per cent) and Erode (34.37 per cent).

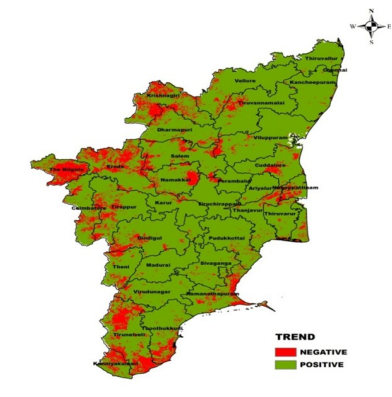

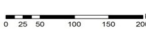

Fig. 3. Spatial map of vegetation trend based on NDVI during Kharif season of 2017 in Tamil Nadu.

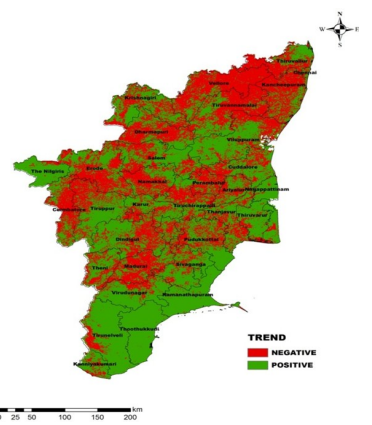

Fig. 4. Spatial map of vegetation trend based on NDVI during Rabi season of 2017 in Tamil

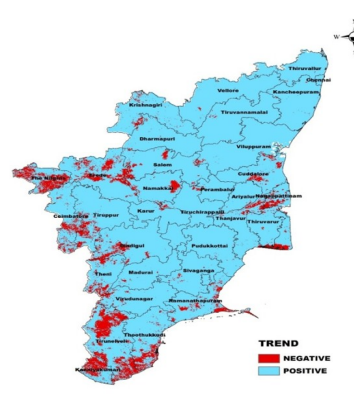
Nadu.

Fig. 5. Spatial map of vegetation trend based on NDWI during Kharif season of 2017 in Tamil Nadu.

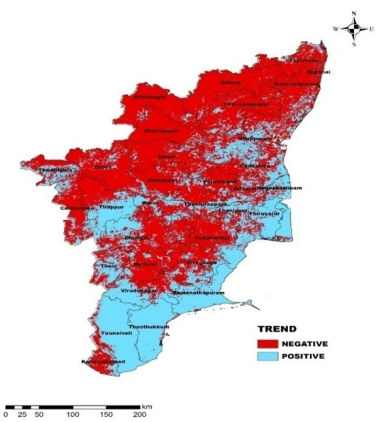

Fig. 6. Spatial map of vegetation trend based on NDWI during Rabi season of 2017 in Tamil Nadu.

In case of land cover of Tamil Nadu (Table 3) it is observed that swamp forest shows a greater percentage of pixels under positive trend (97.47 per cent) followed by cropland (90.74 per cent). In general, Kharif season displays more of a greening (positive trend) compared to Rabi season in Tamil Nadu. The plantation land and scrubland display almost identical type of positive trend of 79.16 per cent and 79.06 per cent. However, the percentage of negative trend remained low in Kharif season where the highest negative trend is seen in forest (29.05 per cent) followed by plantation land (20.84 per cent) followed by scrubland (20.55 per cent)

NDVI trend during Rabi season: During Rabi season (Fig. 8), it is observed that the districts of Tamil Nadu show a mixed positive and negative NDVI trend. The districts of Thoothukudi (99.52 per cent) Ramnathapuram (97.26 per cent), The Nilgiris (92.17 per cent) and Tirunelveli (89.14 per cent) were among few districts that showed higher percentage of pixel under positive NDVI trend. While the areas falling under the districts of Vellore (81.22 per cent) Perambalur (71.79 per cent), Coimbatore (64.30 per cent), Triuvallur (62.17 per cent) and Tiruvannmalai (61.59 per cent) shows negative NDVI trend. 


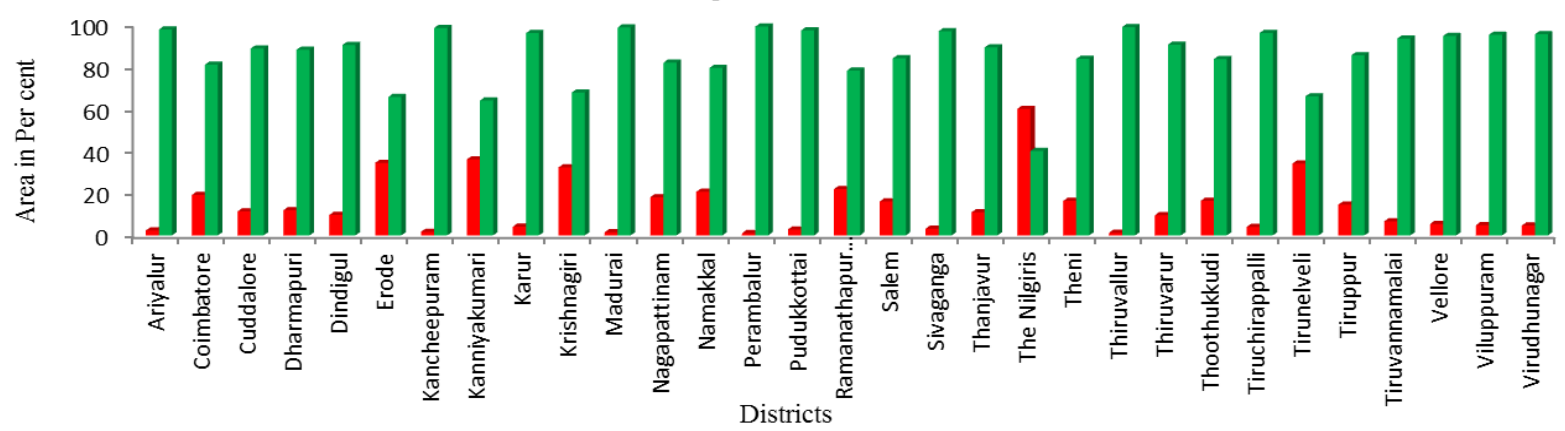

Fig. 7. District wise area in Tamil Nadu showing vegetation trend based on NDVI during Kharif season of 2017

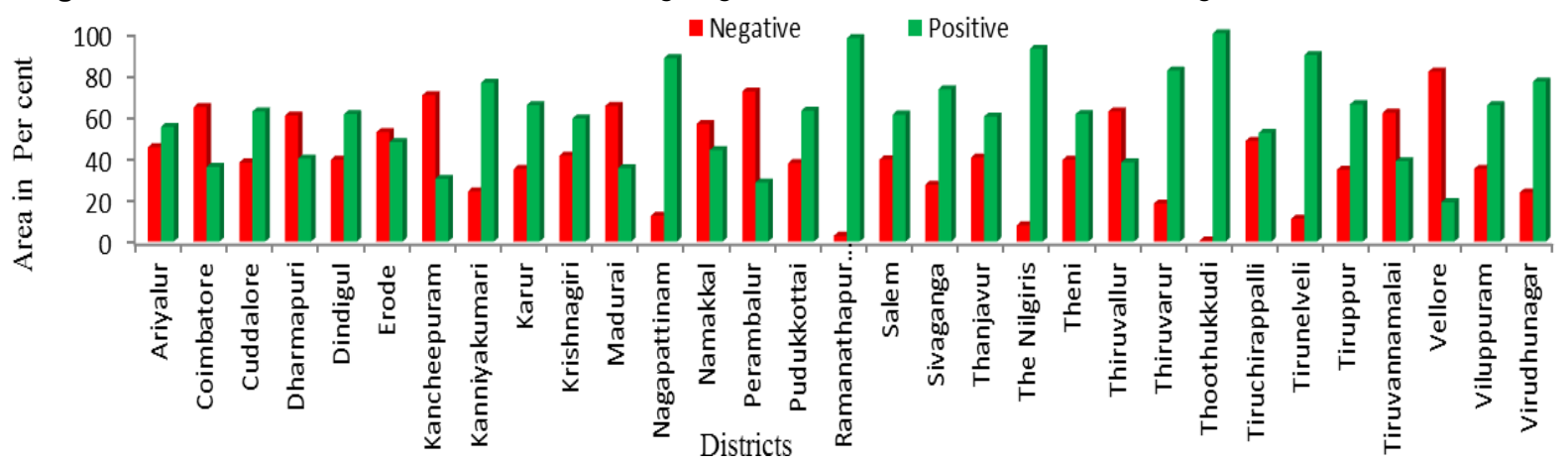

Fig. 8. District wise area in Tamil Nadu showing vegetation trend based on NDVI during Rabi season of 2017

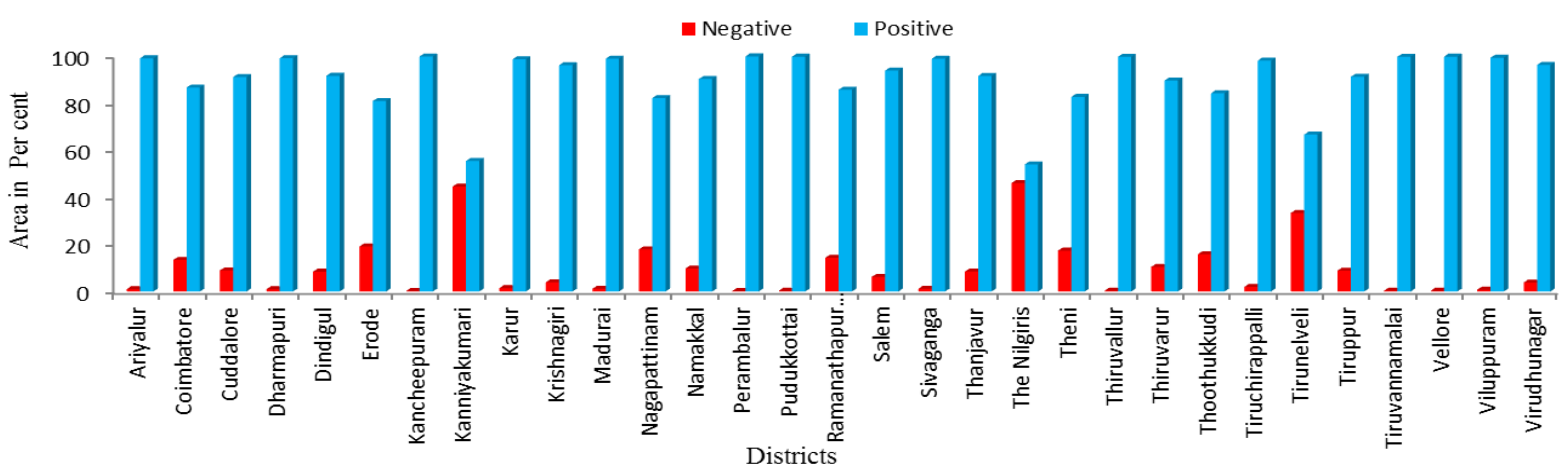

Fig. 9. District wise area in Tamil Nadu showing vegetation trend based on NDWI during Kharif season of 2017

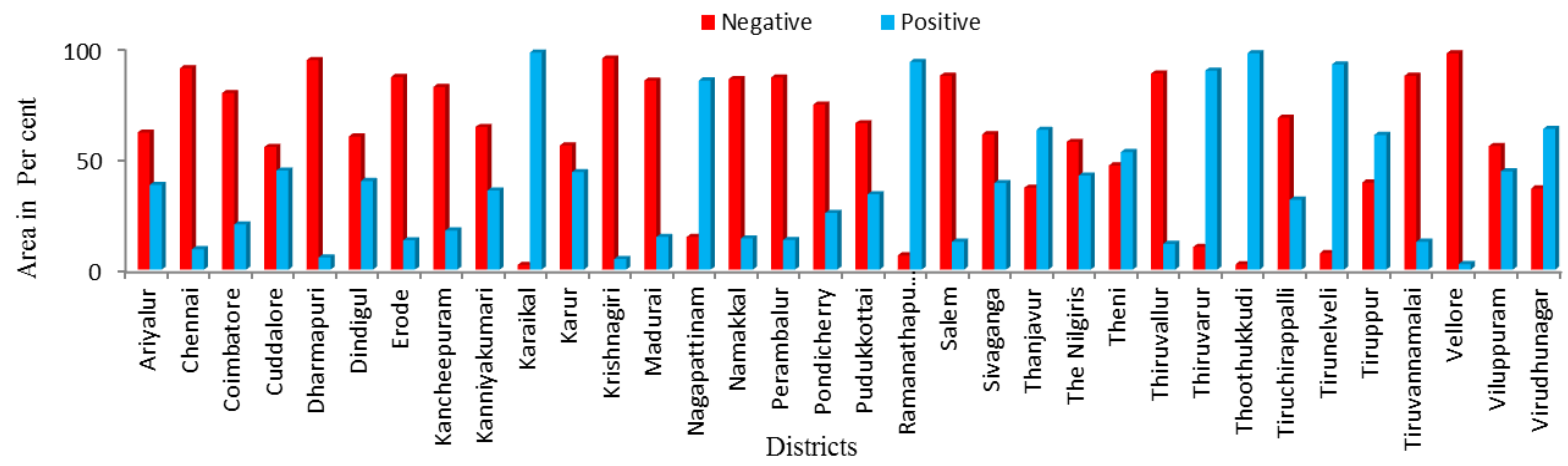

Fig. 10. District wise area in Tamil Nadu showing vegetation trend based on NDWI during Rabi season of 2017

However over the land cover of Tamil Nadu (Table 3) it is observed that there were mixes of pixels under positive and negative trend. Area under cropland showed greater percentage of pixels under positive trend (67.35 per cent) followed by plantation land (64.56 per cent) and for- est area (63.23 per cent), while the highest negative trend was displayed by the swamp forest (55.63 per cent) followed by scrubland (43.16 per cent).

NDWI trend during Kharif season: During Kharif season (Fig. 9), it is observed that except for 
some districts of Tamil Nadu, all other districts experiences positive trend in NDWI. The districts with significant percentage of area under negative trend include The Nilgiris (46.03 per cent), Kanniyakumari (44.58 per cent) and Tirunelveli (33.35 per cent). While among all the other districts the highest percentage of pixel areas under positive trend can be noticed in the districts of Perambalur (99.81 per cent), Pudukkotai (99.69 per cent), Vellore (99.68 per cent), Triuvannamalai (99.65 per cent) and Viluppuram (99.22 per cent).

In case of land cover categories of Tamil Nadu (Table 4) it is observed that swamp forest shows greater percentage of pixels under positive trend (99.77 per cent) followed by cropland (94.43 per cent). The maximum percentage of pixels under forest cover that showed positive trend was observed to be 87.39 per cent. While the highest percentage of pixel area under negative trend is observed for plantation (19.51 per cent) followed by forest (12.61 per cent). While, the least percentage of pixels area is noticed in swamp forest ( 0.23 per cent) and cropland (5.57 per cent).

NDWI trend during Rabi season: During Rabi season, district wise (Fig. 10) it is observed that except for coastal and southern districts of Tamil which include the districts of Thoothukudi (97.61 per cent), Ramanathapuram (93.60 per cent), Tirunelveli (92.54 per cent) and Nagapattinam (85.26 per cent). All the other districts show majority of areas under negative percentage of pixel trend. The districts with maximum areas under negative trend include Vellore (97.49 per cent), Dharmapuri (94.48 per cent), Thiruvallur (88.40 per cent), Salem (87.40 per cent) and Tiruvannamalai (87.39 per cent).

However for land cover categories (Table 4) it is observed that there were mixes of pixels under positive and negative trend. The area under cropland showed a greater percentage of pixel area under positive trend (52.44 per cent) followed by plantation land ( 46.8 per cent). The highest percentage of pixel area under negative trend was displayed by the forest (78.82 per cent) while the scrubland (74.93 per cent) and swamp forest (74.19 per cent) shows similar kind of negative trend. Overall, higher percentage of pixel areas under negative trend was observed for all the land cover categories except for cropland which had 47.56 per cent of pixel percentage under negative NDWI trend.

\section{DISCUSSION}

The present study on seasonal vegetation trend over Tamil Nadu during crop growing season of 2017 showed inter seasonal variation between vegetation greening and vegetation browning. While it was noticed that during Kharif season, majority of area in Tamil Nadu showed vegetation greening however, the district of Nilgiris which comes under hilly agro climatic region of Tamil Nadu showed greater percentage of area under vegetation browning. This could possibly due to terrain conditions in this district and inefficient water management system. Presence of this factor results in rainfall and surface water runoff. This research finding can be put in line with similar results proposed by Tong et al. (2016) in Karst region of South West China, where the author described that persistence of vegetation trend is interrelated with the terrain conditions viz., elevation and slope angle.

The increase in vegetation browning that were noticed in this research work during Rabi season over the Western zone districts (Coimbatore), Northern Eastern zone districts (Trivallur Tiruvannamalai and Vellore) and Cauvery Delta zone districts (Perambalur) of Tamil Nadu could possibly indicates decrease in seasonal rainfall duration with increase in rainfall intensity, as a result percolation times decreases and wastage of rainwater as runoff occurs. Similar works were reported by Nathan, 1998 and Vaani and Porchelvan, 2017 in Tamil Nadu where reports claimed that rainfall decreases from North to South and due to district topography rainfall pattern becomes erratic in time and space. Also in this present study, land covers involving forest areas that has diverse species distributed in different regions and states of Tamil Nadu, involving different growth habits showed a negative vegetation trend. Vegetation browning in forest can be attributed to diverse factors that are not region specific such as leaf fall, the presence of deciduous trees within the forest ecosystem and action of climatic triggers such as precipitation and moisture. These factors changes from region to region as analyzed by Schucknecht et al., 2013 over the forest ecosystem and vegetation dynamics variability and trend in North-Eastern Brazil.

With respect to the seasonal variation over Tamil Nadu, the present study reported that Kharif season displayed more of vegetation greening (positive trend) compared to Rabi season which can be attributed to the increased vegetation growth and productivity during the Kharif season prevailing months as studied by Nemani et al., 2003 and Zhou et al., 2001. While the result of observing a decline in the vegetation greening trend (vegetation browning) over the cropland areas during Rabi season could be the indication of irrigated area contraction and a shift in cropping pattern for more water-demanding crops. Similar results were stated by Milesi et al., 2010 for the irrigated and rain fed croplands present in the water limited tropics (WLT) countries such as India. The presence of greater pixels under negative trend during Rabi season which were observed in this research study is the result of combination of ill-mannered cropland, crop rotation, and vegetation degradation which results increase in bare 
and semi-bare land reflection that shows a scattered and irregular pattern. This result can also be put in line with the works of Chen et al., 2006 where a relation was determined between the vegetation variability caused due to presence of diverse plant species present in the lower Tarim river of Western China. Also, the poor water availability often leads to changes in cropping distribution and crop choice for crops such as rice, cotton, groundnut and sugarcane that a majorly cultivated in Tamil Nadu. As a result vegetation response shows negative trend during the crop growing season according to Dubovyk et al., (2012).

Overall, in the present study using the remote sensing based optical dataset, higher percentage of pixel areas under negative trend was observed for all the land cover categories in Tamil Nadu except for cropland. This could be due to water efficiency strategies adapted by croplands as deep-rooted plants are more buffered from climatic fluctuation than from shallow rooted crop plants. Similar use of remote sensing data and vegetation index were used by Wan et al., 2004 where the author stated that vegetation growth are time independent, region and crop specific and is better used during the plant growing seasons.

\section{Conclusion}

The time series image of both NDVI and NDWI seasonal trend showed majority of area in Tamil Nadu falling under positive trend during the Kharif season (86.52 per cent for NDVI and 90.29 per cent for NDWI). During Kharif season, NDVI response in The Nilgiris district only showed more of area under negative trend (59.98 per cent) while the majority of districts showed greater areas under positive trend. While the district of Kanniyakumari (44.58 per cent), Tirunelveli (33.35 per cent) and The Nilgiris (46.03 per cent) showed greater area under negative trend in case of NDWI response. During Rabi season, a mix of negative and positive NDVI and NDWI trend was noticed. The percentage of area under positive NDVI trend was 59.72 per cent and 40.28 per cent of area was notice under negative NDVI trend. Similarly, 40.26 per cent of area was under positive NDWI trend and 59.75 per cent of area under negative NDWI trend. Irrespective of land cover classes, NDVI and NDWI during Kharif season showed a greater positive trend (greening) with least negative trend (browning) for vegetation growth over the land covers whereas during Rabi season it was observed to have a mix of positive trend and negative trend over the land covers. During Kharif season and irrespective of vegetation index the swamp forest was noticed to have greater percentage of area under positive trend followed by cropland. While during the Rabi season, irrespective of vegetation index cropland fol- lowed by plantation showed greater percentage of pixel areas under positive trend

This study highlighted the consistency of MODIS derived NDVI and NDWI for monitoring and mapping of vegetation growth and development using linear regression trends in various vegetation types. The trend analysis also paved way in identifying the causes for degradation of vegetation coverage. The positive greening of vegetation during the Kharif season can be related to the increased vegetation growth and productivity during this period and the declining vegetation (browning) growth in Rabi season is due to changes in a crop choice and disruption of cropping lands along with external factors such as precipitation, temperature and slope factors acting upon the area and varying from region to region.

\section{ACKNOWLEDGMENTS}

This study was carried out through the Junior Research Fellowship funded during October 2017June 2018 by The Department of Remote Sensing and GIS, Directorate of Natural Resource Management, Tamil Nadu Agricultural University, Coimbatore, India under the NADP (RKVY) Scheme on "Remote Sensing based information for crop coverage, yield estimation and drought monitoring".

\section{REFERENCES}

1. Chen, Y. N., Zilliacus, H., Li, W. H., Zhang, H. F., and Chen, Y. P. (2006). Ground-water level affects plant species diversity along the lower reaches of the Tarim River, Western China. Journal of Arid Environments. 66(2), 231-246. doi: http://dx.doi.org/ 10.1016/ j.jaridenv.2005.11.009.

2. Cuomo, V., Lanfredi, M., Lasaponara, R., Macchiato, M. F., and Simoniello, T. (2001). Detection of interannual variation of vegetation in middle and southern Italy during 1985-1999 with $1 \mathrm{~km}$ NOAA AVHRR NDVI data. Journal of Geophysical Research: Atmospheres. 106(D16), 17863-17876. doi: http:// dx.doi.org/10.1029/2001JD900166.

3. Dubovyk, O., Menz, G., and Khamzina, A. (2012). Trend analysis of MODIS time-series using different vegetation indices for monitoring of cropland degradation and abandonment in Central Asia. In Geoscience and Remote Sensing Symposium (IGARSS). 6589-6592. doi: http://dx.doi.org/10.1109/ IGARSS.2012.6352089.

4. Fensholt, R., Rasmussen, K., Nielsen, T. T., and Mbow, C. (2009). Evaluation of earth observation based long term vegetation trends-Intercomparing NDVI time series trend analysis consistency of Sahel from AVHRR GIMMS, Terra MODIS and SPOT VGT data. Remote Sensing of Environment. 113(9):18861898. doi: http://dx.doi.org/10.1016/j.rse.2009.04.004.

5. Fu, Y. H., Piao, S., Op de Beeck, M., Cong, N., Zhao, H., Zhang, Y., Menzel, A., and Janssens, I. A. (2014). Recent spring phenology shifts in western Central Europe based on multiscale observations. Global ecology and biogeography.23 (11), 1255-1263.

6. Gandhi, G. M., Parthiban, S., Thummalu, N., and 
Christy, A. (2015). NDVI: vegetation change detection using remote sensing and GIS-a case study of Vellore District. Procedia Computer Science. 57, 1199-1210.

7. Gao, B. C. (1996). NDWI- A normalized difference water index for remote sensing of vegetation liquid water from space. Remote sensing of environment. 58(3), 257-266._doi: http://dx.doi.org/10.1016/ S0034-4257(96)00067-3.

8. Gumma, M. K., Nelson, A., Thenkabail, P. S., and Singh, A. N. (2011). Mapping rice areas of South Asia using MODIS multitemporal data. Journal of applied remote sensing. 5(1), 053547. doi: http:// dx.doi.org/10.1117/1.3619838.

9. Guo, X., Zhang, H., Wu, Z., Zhao, J., and Zhang, Z. (2017). Comparison and Evaluation of Annual NDVI Time Series in China Derived from the NOAA AVHRR LTDR and Terra MODIS MOD13C1 Products. Sensors. 17(6), 1298 . doi: http:// dx.doi.org/10.3390/s17061298.

10.Mao, D., Wang, Z., Luo, L., and Ren, C. (2012). Integrating AVHRR and MODIS data to monitor NDVI changes and their relationships with climatic parameters in Northeast China. International Journal of Applied Earth Observation and Geoinformation. 18, 528 -536. doi: http://dx.doi.org/10.1016/j.jag.2011.10.007.

11.Milesi, C., Samanta, A., Hashimoto, H., Kumar, K. K., Ganguly, S., Thenkabail, P. S., Srivastava, A. N., Nemani R. R., and Myneni, R. B. (2010). Decadal variations in NDVI and food production in India. Remote Sensing. 2(3), 758-776. doi: http:// dx.doi.org/10.3390/rs2030758.

12.Nathan, K. K. (1998). Droughts in Tamil Nadu: A qualitative and quantitative appraisal. Drought Network News (1994-2001). 10 (3), 62.

13.Nemani, R. R., Keeling, C. D., Hashimoto, H., Jolly, W. M., Piper, S. C., Tucker, C. J., Myneni B., and Running, S. W. (2003). Climate-driven increases in global terrestrial net primary production from 1982 to 1999. Science. 300(5625), 1560-1563. doi: http:// dx.doi.org/ 10.1126/science.1082750.

14.Piao, S., Fang, J., Zhou, L., Guo, Q., Henderson, M., Ji, W., Li Y., and Tao, S. (2003). Interannual variations of monthly and seasonal normalized difference vegetation index (NDVI) in China from 1982 to 1999. Journal of Geophysical Research: Atmospheres. 108(D14).

15.Ramesh, R., Nammalwar P., and Gowri, V. S.,
(2008). Database on coastal information of Tamilnadu. Report to Environmental Information System (ENVIS). Department of Environment, Government of Tamil Nadu.

16.Schucknecht, A., Erasmi, S., Niemeyer, I., and Matschullat, J. (2013). Assessing vegetation variability and trends in north-eastern Brazil using AVHRR and MODIS NDVI time series. European Journal of Remote Sensing. 46(1), 40-59. doi: http:// dx.doi.org/10.5721/EuJRS20134603.

17. Thenkabail, P. S., Gamage M. S. D. N., and Smakhtin V. U. (2004). The Use of Remote Sensing Data for Drought Assessment and Monitoring in Southwest Asia. Research Report 85, 1-25.

18.Tong, X., Wang, K., Brandt, M., Yue, Y., Liao, C., and Fensholt, R. (2016). Assessing future vegetation trends and restoration prospects in the karst regions of southwest China. Remote Sensing. 8(5), 357. doi: http://dx.doi.org/10.3390/rs8050357.

19.Tucker, C. J. (1979). Red and photographic infrared linear combinations for monitoring vegetation. Remote Sensing of Environment. 8(2): 127-150. doi: http://dx.doi.org/10.1016/0034-4257(79)90013-0.

20.Vaani, N., and Porchelvan, P. (2017). Assessment of long term agricultural drought in Tamil Nadu, India using NDVI anomaly. Disaster Advances. 10(10):1-10

21.Wan, Z., Wang, P., and Li, X. (2004). Using MODIS land surface temperature and normalized difference vegetation index products for monitoring drought in the southern Great Plains, USA. International journal of remote sensing. 25(1), 61-72. doi: http:// dx.doi.org/10.1080/0143116031000115328.

22.Zhang, L. Y., Liu, A. J., Xin, Q., Liu, D. F., and Gan, W. (2006). Trend and analysis of vegetation variation of typical rangeland in Inner Mongolia-a case study of typical rangeland of Xilinguole. Journal of Arid Land Resource Environment. 20(2), 185-190.

23.Zhao, Y., He, C., and Zhang, Q. (2012). Monitoring vegetation dynamics by coupling linear trend analysis with change vector analysis: a case study in the Xilingol steppe in northern China. International journal of remote sensing. 33(1), 287-308.

24.Zhou, L., Tucker, C. J., Kaufmann, R. K., Slayback, D., Shabanov, N. V., and Myneni, R. B. (2001). Variations in northern vegetation activity inferred from satellite data of vegetation index during 1981 to 1999. Journal of Geophysical Research: Atmospheres. 106(D17), 20069-20083. doi: http:// dx.doi.org/10.1029/2000JD000115. 